Modern Asian Studies 52, 3 (2018) pp. 1076-1087. (C) Cambridge University Press 2018 doi:10.1017/Soo26749X17000282

\title{
Whose Public, Whose Authority? Reflections on the moral force of violence
}

\author{
THOMAS BLOM HANSEN
}

\author{
Department of Anthropology, Stanford University \\ Email:tbhansen@stanford.edu
}

\begin{abstract}
In this Afterword I argue that public authority in South Asia is produced in a dynamic interplay between ever-more segmented publics and the ubiquity of highly performative violence. Drawing on Indian examples, I suggest that the success of vernacular publics in producing a sense of cultural intimacy within language communities in turn has prompted a new segmentation of publics. This has occurred along lines of caste and community, defined by social experience and symbols, rather than language as such. The concomitant routinization of violence in public life-whether as physical destruction of public property, attacks on other communities, or as symbolic elevations of victims of violence to the status of martyrs-indicate that today valorization and experiences of violence, however incommensurable, have emerged as a universal medium, or general equivalent, in public and political life in India.
\end{abstract}

\section{Introduction}

The wonderful articles in this special issue reflect the empirical strength and theoretical ambition of a new generation of scholars of South Asia. It is clear from all these articles that the relationship between public authority and violence is of ever-more crucial, if not constitutive, importance to politics and public life across the region. It is also clear that the nature of what constitutes a 'public', and how sentiments and information are disseminated and shared, are rapidly being transformed into a more deeply segmented landscape. This, in turn, has implications for how violence is defined, performed, justified, and legitimized across widely differing linguistic and social worlds.

Let me begin with a small incident that I witnessed during fieldwork in the Muslim-majority districts of central Mumbai in 1996. One of 
the former elected members of the Bombay Municipal Corporation was arrested on charges of racketeering and corrupt practices. The man in question was a small businessman who had been elected on a Congress ticket. He was known as an affable, decent, if somewhat ineffective, man and rumour had it that he had lost his seat because he was not willing to pander to the builders and crime bosses in the area. His wife cried foul. She claimed that he had been framed on false charges and savagely beaten by the police. She announced a hunger strike to demand his release from custody. With a somewhat 'filmi' gesture she had decided that she would stage her protest in front of a well-known kebab restaurant in South Bombay. 'Otherwise, no one will take any notice,' she told me. The next day, the woman camped on the pavement, surrounded by friends and family holding banners and placards denouncing injustice and criminal politicians, written in English, Urdu, and Hindi. The gesture seemed to work: the hunger-striking woman got a brief mention in one of the city's English-language tabloids which, in a somewhat ironic tone, focused on the 'choice location' for her action. Quoting a police source, the big-selling Marathi daily Lokmat bluntly described her husband as 'a notorious criminal', while the local Urdu press almost entirely focused on the arrest of the husband as yet another instance of systemic police bias against Muslims in the city. ${ }^{1}$ Her action lasted but four days and produced no results. By the second day, people's attention had already shifted. Commuters hurried past her and her placards on the busy pavement. In the Muslim neighbourhood, snickering jokes about the cruelty of fasting amid the smell of kebab subsided after a few days. Soon the incident was seen by the locals as just another tragic, if not comic, example of the isolated and inept character of local Muslim politics.

This is a small and banal example of a failed public performance. Political activists know full well that failure, oblivion, or half-failure are common experiences and outcomes of campaigns or public gestures. Yet they persist in their attempts to win public attention and support for their cause or grievance. These persistent efforts and repeated gestures are what produce and solidify the legitimacy of certain registers of conduct and performance. But form and content do not always match.

\footnotetext{
${ }^{1}$ See Mid-Day, 17 March 1996; Lokmat (Marathi), 17 March 1996; and Sahafat, 17 and 18 March 1996 .
} 
As the editors of this special issue point out, public authority, whether built on fear, respect, or sacrifice, is always brittle and based on the persuasiveness of gestures and reputations in the eyes of a certain putative audience.

Staging a public fast is a risky and complex affair because its symbolic success depends entirely on, first, whether the fasting event is sufficiently public and noteworthy to large numbers of people and, secondly, whether enough people deem the fasting body to be sufficiently morally 'clean' and innocent to deserve not to suffer. In our case, neither of those conditions was met. The 'public' was divided by almost incommensurable interpretations, and the moral standing and reputations of the arrested man and his wife were such that neither their suffering at the hands of the police nor the fast were considered generally excessive and unjust.

From this little example, we can draw at least two conclusions that I will address in more detail below. First, publics in India are not just divided by language-vernacular versus English-as has been the major theme in the literature on modern publics in South Asia. There are multiple parallel, segmented publics defined by community, political persuasion, religion, and caste. These publics may well be using the same natural language but their structure and mode of address, the emotions, myths, and moral universe that define them are either unintelligible or unacceptable to those inhabiting an adjacent public. Secondly, while these publics share a number of ritual and normative conventions regarding how authority is generated and performed (such as the public fast, the dharna, the strike, the crowd protests, public oratory), there are also important differences between them. The most defining differences between these publics in contemporary India concern what I propose to call 'the moral force of violence', that is how different kinds of violence (say, statesanctioned violence, crowd violence, spontaneous violence, retributive violence, historical/structural violence, and so on) are experienced and valorized.

\section{Segmented publics: from institutional networks to communities of experience}

There is a distinguished body of scholarly work tracing the emergence of what one can call 'modern publics' in South Asia. One body of work focuses on the range of debates and discourses that unfolded 
in distinct publics in pre-colonial and early modern South Asiahowever circumscribed they may have been by rank and limited access to Sanskrit or other formal languages. ${ }^{2}$ Another body of work has focused on public rituals, processions, and religious festivals as distinct forms of public expression and contestation, which became the focus of much colonial anxiety and regulation, as well as the basis for the mobilization of anti-colonial sentiments and protests of many kinds. ${ }^{3}$ Some of these works have shown in compelling detail how these mass rituals have been adapted and captured by contemporary political forces. ${ }^{4}$ A third body of work has focused on the emergence of an institutionalized public sphere in colonial and post-colonial India, defined by vernacular newspapers, language standardization, and the development of distinct styles of oratory. ${ }^{5}$ Much of this work has demonstrated the emergence of powerful language ideologies that drove movements for purification and the reinvention of modern vernaculars that could overcome traditional social and caste-defined diglossia as well as the sense of inferiority vis-à-vis English that was reproduced on a daily basis in the vernacular press and in institutions of government, science, and higher

${ }^{2}$ Pollock, Sheldon (2001). 'India in the Vernacular Millennium. Literate Culture and Polity, 1000-1 500' in Public Sphere and Collective Identities, (eds) Shmuel Eisenstadt, Wolfgang Schluchter and Bjoern Wittrock. New Brunswick, NJ: Transaction Publishers, pp. 41-74; Fisher, Elaine (2017). Hindu Pluralism. Religion and the Public Sphere in Early Modern South India. Berkeley: University of California Press; Novetzke, Christian Lee (201 1). Religion and Public Memory. A Cultural History of Saint Namdev in India. New York: Columbia University Press.

${ }^{3}$ Freitag, Sandria (1993). Collective Action and Community. Public Arena and the Emergence of Communalism in North India. Delhi: Oxford University Press; Pandey, Gyanendra (1990). The Construction of Communalism in Colonial North India. Delhi: Oxford University Press; Masselos, Jim (2007). The City in Action. Bombay Struggles for Power. Delhi: Oxford University Press.

${ }^{4}$ Kaur, Raminder (2005). Performative Politics and the Cultures of Hinduism. Public Use of Religion in Western India. London: Anthem Press; Guha-Thakurta, Tapati (2015). In the Name of the Goddess. The Durga Puja of Contemporary Kolkata. Delhi: Primus Books; Michelutti, Lucia (2009). The Vernacularisation of Democracy. Politics, Caste and Religion in India. London/Delhi: Routledge.

${ }^{5}$ Orsini, Francesca (2009). The Hindi Public Sphere 1920-40. Language and Literacy in the Age of Nationalism. Delhi: Oxford University Press; Lelyveld, David (1978). Aligarh's First Generation. Muslim Solidarity in British India. Princeton: Princeton University Press; Ghosh, Anindita (2006). Power in Print. Popular Publishing and the Politics of Language and Culture in Colonial Society. Delhi: Oxford University Press; Bhargava, Rajeev and Reifeld, Helmuth (eds) (2005). Civil Society, Public Sphere and Citizenship. Delhi: Sage Publications; Mir, Farina (2010). The Social Space of Language. Vernacular Culture in British Colonial Punjab. Berkeley: University of California Press. 
learning. ${ }^{6}$ In combination with the continuing hegemony of English as the language of reason, polite society, law, modernity, big business, and what is known in India today as so-called 'world class' standards, these effective language movements have had the peculiar effect of enabling the vernacular publics to be experienced as culturally intimate in a way that is historically unprecedented. The vernacular is now that which can be shared and mobilized with many strangers as a medium of intimacy and solidarity vis-a-vis outsiders, as in the case of the regional movements in Andhra Pradesh, Maharashtra, and Tamil Nadu. It may also be the medium of less restrained and more nakedly majoritarian sentiments, as indicated by Arvind Rajagopal in his wellknown analysis of how a public split between a more formal Englishspeaking public and a more intimate Hindi sphere became a central enabling condition for the phenomenal expansion of Hindu nationalist sentiments and discourse in the 1980 os and $1990{ }^{8}{ }^{8}$ In his analysis of the Hindi newspaper scene in North India, Per Staahlberg has shown that many local newspapers and journalists pride themselves on being 'closer to the emotions of the people'. 9

The vernacular language itself-its grammar, the joy of speaking it, the sharing of references, and the sense of community it engendersare in many cases a site of condensed emotions and a thick sense of community, as Bernard Bate has shown for the non-Brahman movement in Tamil Nadu. ${ }^{10}$ Clare Talwalker's analysis of language community among middle-class Marathi speakers demonstrates that

\footnotetext{
${ }^{6}$ Naregal, Veena (2001). Language, Political Elites and the Public Sphere. Western India Under Colonialism. London: Anthem Press; Mitchell, Lisa (2009). Language, Emotion and Politics in South India. The Making of a Mother Tongue. Bloomington: Indiana University Press; Mantena, Rama, S. (2013). 'Vernacular Publics and Political Modernity: Language and Progress in Colonial South India', Modern Asian Studies, vol. 47, no 5 , pp. $1678-1705$.

See the ongoing work by Ravinder Kaur tracing the emergence and effects of the global rebranding of India-all in English. Kaur, Ravinder (2016). 'Post-exotic India: On Remixed Histories and Smart Images', Identities: Global Studies in Culture and Power, vol. 23, no. 3, pp. 307-326.

${ }^{8}$ Rajagopal, Arvind (2001). Politics After Television. Hindu Nationalism and the Reshaping of the Public in India. Cambridge: Cambridge University Press.

${ }^{9}$ Staahlberg, Per (2002). Lucknow Daily. How a Hindi Newspaper Constructs Society. Stockholm: Almquist and Wiksell International; Staahlberg, P. (2014). 'Population and Publics in Indian Communication Society', Media International Australia, no. 152, August 2014, pp. 158-167. On the Gujarati language press in 2002, see also GhassemFachandi, Parvis (201 2). Pogrom in Gujarat. Nationalism and Anti-Muslim Violence in India. Princeton: Princeton University Press, pp. 59-93.

${ }^{10}$ Bate, Bernard (2009). Tamil Oratory and the Dravidian Aesthetics. Democratic Practice in South India. New York: Columbia University Press.
} 
the sharing of both modern and classical Marathi enables what she calls 'kin-fetishism' - an imagined world of familial intimacy and commonality where everyone becomes 'uncle', sister, brother, and so on. This world thrives, she argues, on its supposed contrast to what is perceived to be the more alienating world of stranger sociality that characterizes a world of deep capitalist transformation. ${ }^{11}$

This sense of a vernacular as a shield against a larger, often hostile, world is very powerful indeed among many Muslims for whom Urdu has become what Asif Khan, late cartoonist and journalist in Mumbai, called 'our ethnic language'. In one of our many conversations, he clarified: 'Urdu used to be the second national language of India. A generation ago, everybody spoke it, like a kind of Hindi with many Persian words in it. Today, most of my Hindu friends insist they don't understand it. And no-one else but us reads our newspapers.' For Asif and many others, Urdu had become culturally intimate; a familial, almost anachronistic, code in a diminished and often isolated public; enjoyable and infuriating, just like kin.

If the spectacular success of vernacular media-newspapers, TV channels, and websites in recent decades-has produced an enhanced sense of vernacular cultural intimacy, the same process has also produced a distinct unease with the putative kinsmen included in the language community. As Talwalker indicates, kin fetishism has distinct limits and vulnerabilities because it is founded on a preexisting, if unstated, premise of social and ritual compatibility among upper caste Hindus. ${ }^{12}$ Some of the most inventive and irreverent writers in Marathi in the past decades are indeed Dalit writers and public intellectuals who both are, and are not, included in the intimacy of modern Marathi. For these figures, mastery of the vernacular is both a platform for critique and a claim for recognition, not through intimacy but through the creation of a parallel Dalit public sphere, marked by festivals, institutions, and symbols that are neither generally known, nor recognized by the average caste Hindu in the state. ${ }^{13}$ Like many other segmented publics, the Dalit public sphere in Maharashtra is perfectly knowable but not generally known. It is technically public in a linguistic sense but not in a social sense. What

\footnotetext{
${ }^{11}$ Talwalker, Clare (2009). 'Kindred Public: The Modernity of Kin Fetishism on Western India', Postcolonial Studies, vol. 12, no. 1, pp. 69-88.

${ }^{12}$ Ibid., p. 86.

${ }^{13}$ For decades the large crowds attending the anniversary of Ambedkar's death at the Chaityabhoomi located in the upmarket neighbourhood of Dadar in Mumbai have provoked much anger and resentment among local caste Hindus.
} 
holds such publics together is a shared experience of stigmatization, a shared moral universe, and a claim for recognition as full citizens and humans that cannot be fully captured through the conventional idea of a public sphere as a network of institutions, texts, and linguistic performances. The Dalit public sphere, like other emerging lowercaste publics, is centrally organized around the assertion of democratic and constitutionally guaranteed rights in opposition to the cultural and social hegemony of upper-caste Hindus. In those senses these publics are indeed 'counter publics', deriving energy and motivation from direct challenges to the often hidden and naturalized social life of caste distinction. ${ }^{14}$

However, the fragmentation of publics in this more subtle sense of smaller and discrete 'communities of experience' is a more finegrained affair that is often somewhat removed from the rough and tumble of electoral politics. Let me return to the sense of a diminished Urdu public which is lamented among many educated Muslims in central Mumbai. In these quarters the decline of Urdu is experienced as a loss of a certain cultural sophistication and refinement. In its stead there is a new public prestige of more Arab-type forms of Muslim pious speech promoted by organizations like the Tablighi Jamaat, as well as coarser and more popular forms of culture, comportment, and patterns of speech associated with the substantial number of migrants from Bihar and Bhojpuri-speaking areas in North India. Relentless pressure from Hindu majoritarian forces have also contributed to the marker 'Muslim' being the most defining feature of public life in these historical neighbourhoods. Majid, another local Urdu journalist, told me, 'In the mainstream press we are all lumped together as Muslims, we are all seen as clannish and half criminals ... no matter what I say or do, people will only look at my name and say, oh but he is Muslim. I am already guilty.'

For this journalist and many others, this represented a decline from an earlier time in the life of the post-colonial state where one could inhabit a wider public sphere created by the nationalist movement. This would never be as the ideal figure of the unmarked citizen conjured up in normative theories of the public sphere, perhaps,

\footnotetext{
${ }^{14}$ See Warner, Michael (2005). Publics and Counter Publics. New York: Zone Books. See also M. S. S. Pandian's incisive discussion of how caste politics is not 'behind' modernity but rather at the very vanguard of the unfolding of modern freedoms and claims to equality in India. Pandian, M. S. S. (2002). 'One Step Outside Modernity. Caste, Identity Politics and Public Sphere', Economic and Political Weekly, vol. 37, no. 18 , pp. $1735^{-1} 74^{1 .}$
} 
but nevertheless as a member of a larger public where one could speak on behalf of a neighbourhood, a demand, a profession, or a political persuasion without a priori being reduced to one's cultural or religious identity. The politician's wife in the story with which I began this article naively assumed that she could perform her role as a disaffected citizen, unjustly victimized by police brutality and corruption. That position, my friends explained, was not available because, as a Muslim, she was 'already guilty'. To make matters worse, they added, 'her husband was not seen as a good Muslim so the pious ones did not support her either'.

To sum up: the vague ideals of a 'general public' in the post-colonial nation are still alive in Bollywood films, commercial advertising, and other media but they have been challenged by the spectacular success of multiple vernacular publics and the intensification of cultural intimacy and intense political community along linguistic lines. In turn this 'vernacularization' has reinforced another kind of segmentation of discrete publics along the lines of the distinct social and cultural experiences of caste and community or more fleeting and situational publics coalescing around shared feelings of hurt and deprivation. It is to the central role of violence in connecting different segments of public life that I will now turn.

\section{Violence as a general equivalent}

As explored by every contributor to this special issue, violence has played a central role in political life across post-colonial South Asia. Unlike many other countries in the region where coups, civil wars, and prolonged armed conflicts define political life and public memory, violence in India has primarily been associated with more dispersed forms of 'public violence' such as communal riots or with clashes between protesters and the police. Less noticed has been a steady increase in routine public violence, such as the destruction of public property-buses, police vans, offices, schools-by protesters of many kinds. It is difficult to open a newspaper today without reading at least one story about what police records describe as acts of 'vandalism'. Most often protesters describe such events as the inevitable effect of pent up anger and outrage, as if the scale of physical destruction is an index of the depth and intensity of their rage. Protesters want the government and various publics to take note, and the reactions are invariably mixed if not contradictory. Even though the spectacular 
protests staged by Patidars and Jats in Gujarat in March 2016 were condemned as vandalism by the authorities and most of the Englishand Hindi-language press, a point was being made and registered: there is considerable anger and frustration with the reservation system as it currently works. Among these caste communities, the very scale of the rallies and protests were in themselves projected as victories and they catapulted a new and young leadership into unprecedented positions of authority and influence in their respective 'caste publics'.

The same logic applies to a wide range of similar instances of performing anger in public, an anger invariably presented as emanating from collective hurt feelings. Amelie Blom and Nicholas Jaoul argue that such language of outrage and hurt pride has today become the predominant modality of public violence in India. ${ }^{15}$ It came to the fore in the movements for linguistic states whose martyrs are celebrated to this day, from Tamil Nadu to Maharashtra and Assam. It was Shiv Sena, the primary heir to this particular politics of popular emotion of the $195^{\circ}$ and 1960 , that worked up fury (raag/Marathi) and anger (gussa/Hindi) into public virtues. This is an increasingly legitimate style of politics whose forceful directness (seeda marpeet) against authorities and the perceived enemies of the ordinary Marathi speaker indexed its authenticity and association with a rougher plebeian world. ${ }^{16}$ This sentiment is directly relayed by the name of Shiv Sena's newspaper Saamna (Confrontation), which has been pivotal in making a coarser style of colloquial Marathi acceptable and legitimate, even if it is always dismissed as being in 'poor taste' by the traditional upper-caste and middle-class communities who claim to uphold the language community's core cultural values.

Hindu communal politics was conventionally and historically framed as self-defence against perceived Muslim aggression. However, since the 1980s, Hindutva discourse has increasingly adopted a style of forceful anger that foregrounds hurt sentiments-such as the projection of the historical humiliation of Hindus by the very existence of the Babri Masjid on the putative birthplace of Lord Ram-or

\footnotetext{
${ }^{15}$ Blom, Amelie and Jaoul, Nicholas (2008). 'Introduction: The Moral and Affectual Dimension of Collective Action in South Asia', South Asia Multidisciplinary Academic Journal (SAMAJ), no. 2, https://samaj.revues.org/1912, [accessed 14 March 2018].

${ }^{16}$ Eckert, Julia (2003). The Charisma of Direct Action. Power, Politics and the Shiv Sena. Delhi: Oxford University Press; Hansen, Thomas Blom (2001). Wages of Violence. Naming and Identity in Postcolonial Bombay. Princeton: Princeton University Press; Sen, Atreyee (2007). Shiv Sena Women. Violence and Communalism in a Bombay Slum. Bloomington: Indiana University Press.
} 
the theme of hurt pride (garav) that was so prominent during the 2002 anti-Muslim pogrom in Gujarat. ${ }^{17}$ In these public actions, even excessive and cruel violence is purified and made just and moral by the imputed injury to a community or a collective emotion that provoked it in the first place. Violence is purely reactive, spontaneous, and therefore just. It is 'natural n'yaya (justice)', as a Shiv Sena activist in Mumbai put it to me many years ago-something that is inherent in a brave and self-respecting man: 'If someone slaps me, my hands come out and I slap him. It is natural n'yaya.'

This modality of forceful and violent action, which appeals to a 'general public' as well as more specific publics defined by movements and distinct communities, is only one of several ways in which violence and injury has come to play a pivotal role in public life in contemporary India. But two other major, and more celebrated, traditions in Indian political life are equally focused on violence, albeit in a different manner. One is the Gandhian tradition of non-violence (ahimsa) performed either as passive resistance or as fasting and hunger strike. In this modality, the willingness to suffer the blows of the lathi or the pains of hunger reverses the force of violent action (hinsa) and reveals the cruelty and excess of the perpetrator's action. This form of public sacrifice depends squarely on the dominant presence of violence by the state or other powerful entities. It is only effective, however, when the suffering body a priori can be defined as inherently good or as possessing moral and political authority. If this is not the case, as in my example of the fasting woman, who was faulted for being Muslim, but also not Muslim enough, there is no authority to be derived from such a reversal of violence. ${ }^{18}$

A second register of political action and public performance is that of the martyrdom of the suffering body. This is a theme of deep religious significance in various Hindu traditions, in Sikhism, the

${ }^{17}$ The theme of collective hurt emotions has now become the predominant motif in Hindu nationalist mobilization. The movement claims that scholars and writers, such as Wendy Doniger, offend Hindu feelings and that the English-language press, or critics of the Modi government, disregard the true sensibilities of Hindus, and so on.

${ }^{18}$ I have explored this distinction between bodies that can perform self-sacrificial acts, and those that cannot, in T. B. Hansen, 'The Sacrificial Self. Recasting Renunciation in South Asia', Kingsley Martin Memorial Lecture, University of Cambridge, 2014. For recent discussions of the violence implied in non-violence, see Devji, Faisal (2012). The Impossible Indian. Gandhi and the Temptation of Violence. Cambridge, MA: Harvard University Press; Skaria, Ajay (2016). Unconditional Equality. Gandhi's Religion of Resistance. Minneapolis: University of Minnesota Press. 
Shi'ite tradition, Christianity, and a powerful discourse among radical Islamists, Sikh militants, and the contemporary Maoist movement in South Asia. ${ }^{19}$ Interestingly, a less heroic modality of this discourse has become central to diverse movements and public performances that project the suffering and deaths of marginalized and oppressed communities as a form of sacrifice. In the Dalit movement, the motif of the dead and wounded body, and the remembering of those killed and martyred (shaheedi), have become central to the calendar and choreography of public events. ${ }^{20}$ Similar valorizations of those killed in confrontations with the police, or displaced and disenfranchised as victims and martyrs, have become extremely widespread throughout India and the rest of South Asia. While a morally compelling and powerful strategy that makes violence a central motif and force in political life, some communities also harbour doubts about occupying such a ready-made 'victim's slot'. To many of my Muslim informants in central Mumbai, shaheedi has to be connected with action and with courage (sahaas), not merely with victimhood. They deplore the fact that the heroic stature of the shaheed has been so successfully claimed by radical Islamists, while ordinary Muslims are reduced to victims without scope for action. As a young Gulf returnee told me: 'What is there to do when they [the Hindus] attack us-we have let ourselves become qurban (a sacrificial animal/object).'

Violence, I propose, has become a form of 'general equivalent' in India's multiple publics, akin to Marx's notion of money as the general measure of value of otherwise disparate objects and relationships (commodities, capital, debt). Acts of public violence generate wildly disparate experiences and interpretations of violence-avenging, retributive, sacrificial, or victimizing. Often, the experiences and accounts of violence are entirely incommensurate with one another, such as in the divided and disparate reckoning after major communal riots and other crowd violence. At other times, violence is invisible and incomprehensible to an adjacent public and social world, as in routinized atrocities against Dalits, or the systematic, daily structural

\footnotetext{
${ }^{19}$ Axel, Brian (2001). The Nation's Tortured Body. Violence, Representation and the Formation of a Sikh 'Diaspora'. Durham: Duke University Press; Devji, Faisal (2009). The Terrorist in Search of Humanity. Militant Islam and Global Politics. New York: Oxford University Press; Lecomte-Tilouine, M. (2010). 'Martyrs and Living Martyrs of the People's War in Nepal', SAMAJ, no. 4, https://samaj.revues.org/3018, [accessed 14 March 2018].

${ }^{20}$ Rao, Anupama (2009). The Caste Question. Dalits and the Politics of Modern India. Berkeley: University of California Press
} 
violence visited upon Muslims and other minorities across the country. Yet-and this is the point-these experiences and real events are invariably presented as instances of extra-legal, excessive, and exceptional public violence in order to become visible and intelligible across deeply segmented, and antagonistic, public worlds. While the thick social context and experience of violence are difficult to translate, the figures of victims, outraged crowds, or the self-sacrificing activist are general equivalents that transcend deeply segregated and segmented social and cultural worlds.

Modern democracy thinkers, like Hannah Arendt, Habermas, and many others, see violence as the limit, if not negation, of political life and civil political discourse. However, it is clear from the articles in this special issue that violence has become a completely routinized and integral part of political life in India's many diverse publics. Violence is a form of ultimate action that demands attention, a form of experience that generates reaction. It is one of the most powerful ways of communication, and a repertoire of public performance that has become deeply intertwined with the more formal, mediated, and institutional aspects of India's modern publics such as newspapers, news channels, and social media. As Francis Cody has shown in compelling detail, newspaper reporting and opinion pieces in the Tamil press always factor in the possibility of violent reprisals in the wake of controversial statements. ${ }^{21}$ Similarly, Samna and other rightwing newspapers are open about their reporting bias (or 'truth', as their reporters insist) and they routinely urge their readers to take 'direct action' against their enemies. ${ }^{22}$ The street and the editorial office are no longer categorically different in contemporary India, one civil and objective, the other partisan and rogue. They are parts of the same vernacular publics where the open performance of anger and fury is considered every bit as legitimate as a sarcastic opinion piece.

In contemporary India and South Asia, violence is no longer politics by other means. It is political life itself, by all means.

\footnotetext{
${ }^{21}$ Cody, Francis (2015). 'Populist Publics. Print Capitalism and Crowd Violence Beyond Liberal Frameworks', Comparative Studies of South Asia, Africa and the Middle East, vol. 35 , no. 1 , pp. $5^{\mathrm{O}-6}$.

${ }^{22}$ See also Ghassem-Fachandi's compelling account of reporting in mainstream Gujarati newspapers in 2001-2002: Ghassem-Fachandi, Pogrom in Gujarat.
} 